\title{
Diagnostic Function for Assessing Municipal Authorities' Activities Effectiveness
}

\author{
Aleksey Molchan \\ Institute of Economics, Management and Business \\ Kuban State Technological University \\ Krasnodar, Russia \\ molchan.alexey@gmail.com \\ Svetlana Solonina \\ Institute of Economics, Management and Business \\ Kuban State Technological University \\ Krasnodar, Russia \\ svevic@mail.ru
}

\begin{abstract}
The purpose of this article is to present the results of a scientific study, one of the tasks of which is to study the principles and functions of assessing the effectiveness of the activities of municipal authorities in Russia to put forward proposals for improving the assessment methodology, which is important for increasing the pace of socio-economic development of municipalities. The research used methods of modeling and algorithmization, comparative and expert analysis, and a systematic approach. Scientific works of domestic scientists and regulatory framework on the indicated topics became study basics. An expert assessment of conditions importance for a municipal formation management was carried out. As a result of the research, the object of assessment was clarified, an assessment method was proposed using the stratification of municipalities by clusters: period - conditions result, which increases the quality of diagnosing problems and reserves for the development of municipalities. On the example of national problem - the places lack in municipal preschool educational institutions, a measures system to improve the quality of diagnosing the municipal executive authorities' activities effectiveness is presented. The main conclusion of the study is the need to establish a connection between the results of management and the conditions for their achievement to improve the quality of diagnostics of the efficiency of the activities of the municipal government, contributing to sound planning in the region.
\end{abstract}

Keywords-municipal executive authorities, performance assessment, clusters.

\section{INTRODUCTION}

The task of controlling the authorities of the territory administration is an important state task at all times and in all countries. Several documents have been issued in the Russian Federation regulating the assessment of the effectiveness of government bodies, both at the regional and municipal levels.

In the Table 1 the main documents of the federal level are presented, concerning assessing the effectiveness of local self-

\author{
Inna Korkishko \\ Research Center \\ Krasnodar Higher Military School \\ Krasnodar, Russia \\ inna.korkishko.68@mail.ru
}

government bodies (hereinafter LSG), which are constantly updated or supplemented. Each constituent entity of the Russian Federation, per federal regulations, develops its own, specifying the procedure for assessing the effectiveness of local government bodies concerning the conditions of management in the region. The formation of the criterion apparatus is passive; no changes are made to it at the regional level. The procedure for assessing the effectiveness of local self-government bodies is a form of in-house control over the achievement of the necessary indicators of socio-economic policy by municipal authorities, which is of particular relevance for leveling the disproportions in the development of territories, and, ultimately, for improving the well-being of residents. However, experts note that the imbalance in development is not diminishing.

TABLE 1. FUNDAMENTAL REGULATIONS (COMPILED BY AUTHORS)

\begin{tabular}{|l|c|c|}
\hline № & \multicolumn{1}{|c|}{ Title of the act } & \multicolumn{1}{|c|}{ Source } \\
\hline 1 & $\begin{array}{l}\text { «On assessing the effectiveness of the } \\
\text { activities of local self-government bodies of } \\
\text { urban districts and municipal districts» [1] }\end{array}$ & $\begin{array}{l}\text { Decree of the } \\
\text { President of the Russian } \\
\text { Federation dated April } \\
28,2008, \text { No. 607 [1] }\end{array}$ \\
\hline 2 & $\begin{array}{l}\text { On the implementation of the Decree of } \\
\text { the President of the Russian Federation of } \\
28.04 .2008 \mathrm{~N} 607 \text { "On assessing the effectiveness } \\
\text { of local government bodies in urban districts and } \\
\text { municipal districts"> [2] }\end{array}$ & $\begin{array}{l}\text { Order of the } \\
\text { Government of the } \\
\text { Russian Federation of } \\
11.09 .2008 \text { No. 1313-r } \\
\text { [2] }\end{array}$ \\
\hline 3 & $\begin{array}{l}\text { "On the approval of statistical tools for } \\
\text { organizing federal statistical monitoring of the } \\
\text { state of the economy and social sphere of the } \\
\text { municipality" [4] }\end{array}$ & $\begin{array}{l}\text { Rosstat order of } \\
\text { November 29, 2011 N } \\
472 \text { [4] }\end{array}$ \\
\hline 4 & $\begin{array}{l}\text { "On measures to implement the Decree of the } \\
\text { President of the Russian Federation of April 28, } \\
\text { 2008 N 607" On assessing the effectiveness of } \\
\text { local government bodies in urban districts and } \\
\text { municipal districts "and subparagraph" i "of } \\
\text { paragraph 2 of the Decree of the President of the } \\
\text { Russian Federation of May 7, 2012 N 601 "On the } \\
\text { main directions of improving the public } \\
\text { administration system" "[3] }\end{array}$ & $\begin{array}{l}\text { Resolutions of the } \\
\text { Rovernment of the } \\
\text { Recember 17, 2012, N } \\
1317 \text { [3] }\end{array}$ \\
\hline
\end{tabular}


And this is not the only drawback of the existing domestic system for assessing the effectiveness of the activities of municipal authorities.

\section{LITERARY REVIEW}

Many domestic scientists considered the problem of assessing the effectiveness of the activities of municipal authorities, which proves the relevance of this issue. Among them are such as Balykhin A.G. [5], Belyaeva O.I. [6], Voroshilov N.V. [8], Gracheva A.V. [9], Zhura S.E. [10], Ibragimov R.M. [11], Korchagina T.S. [13], Lubashev E.A. and Lukin M.T. [14], Nesterova T.V. [16], Presnyakova T.S. [17], Sabyna E.N. and Sabyna M.N. [18], Sinyavsky F.A. [19], Fugalevich E.V. [20], Chagina A.V. and Vilchinskaya O.V. [21], Shchurilov A.V. [22]. Despite many interesting scientific findings, the issue of assessing the effectiveness of the activities of municipal authorities remains controversial and relevant for many years. Most of the authors of the study of the qualitative aspect of the activities of municipal authorities suggest assessing by calculating a complex integral indicator of efficiency (Belyaeva O.I. [6], Shchurilov A.V. [22]), obtained based on statistical data according to certain criteria, which is already implemented in the federal methodology for assessing the effectiveness of activities. Scientists-researchers usually develop their system of evaluation criteria (Korchagina TS [13], Fugalevich EV [20], Sinyavsky FA [19], Sabyna EN, and Sabyna MN [18]) or propose to make changes to the calculation method (Nesterova TV [16]). They use comparative analysis of indicators as the main method for solving the estimation problem. The indicators are compared between municipalities or with normative indicators (if established).

The created state regulatory and legal framework for the formation of a system for assessing the effectiveness of local self-government bodies contributes to obtaining information on the state of the municipal socio-economic system following the established indicators of socio-economic policy. However, the existing assessment system does not determine the degree of participation of the municipal government in achieving results, especially taking into account the specifics of the conditions for the development and management of the municipal formation.

In addition, no matter how effective the activity of the municipal authorities of individual urban districts and municipal districts of the region is, a high degree of efficiency of regional management is achieved only by a high quality of balanced development of all elements of the regional socioeconomic system. "At the same time, the efficiency of the municipal economy significantly affects the standard of living and economic growth" [7, p. 27].

Therefore, the authors believe it is necessary to comprehensively influence the development of municipal socio-economic systems through an assessment of the effectiveness of the activities of municipal executive bodies within the existing federal system of criteria with their cascade refinement at the regional sectoral level in two directions: conditions and results.

\section{RESEARCH METHODS}

The authors propose to change the approach to assessing the effectiveness of activities based on the principles of system analysis and to improve the quality of diagnosing problems and reserves in the management of the development of municipalities, apply the method of cluster analysis. Cluster differentiation of indicators for assessing the effectiveness of the activities of municipal authorities is not original. But the stratification of municipalities proposed by other scientists is usually one-dimensional (result) or flat (time period-result)

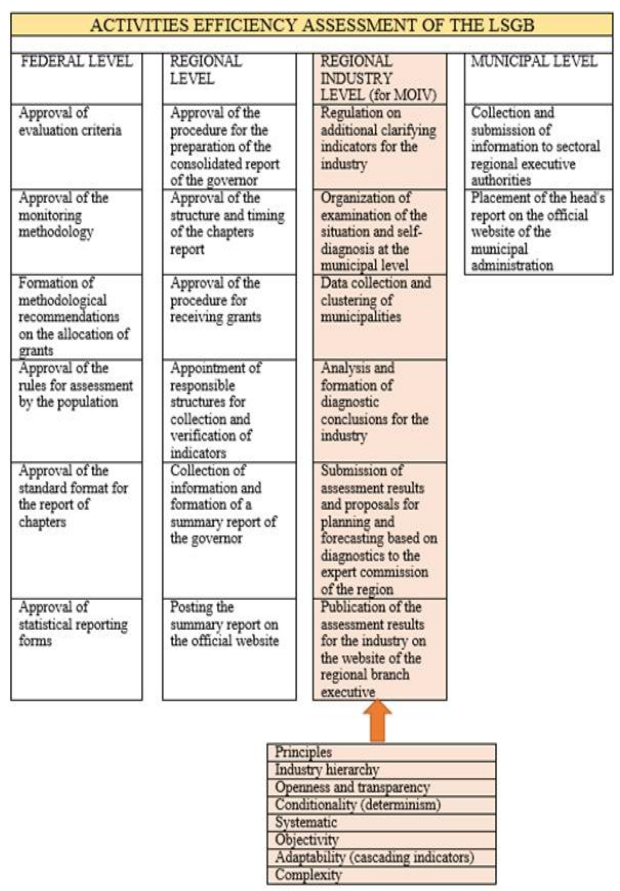

Fig. 1 - Author's model for local self-government bodies effectiveness assessing (author's scientific result)

and does not take into account the principle of determinism: the conditionality of obtaining a result. The authors of the article propose to use a different cluster analysis - volumetric: period-conditions-result and the author's assessment model, which can be easily integrated into the existing one. The comparative analysis is applied within the framework of one cluster, but in two directions: 1) compliance of the conditions with the recommended (necessary), 2) compliance of the performance results with the standards or comparison of the performance results of municipal government bodies from the same cluster with each other.

In addition, the authors of the present study consider it necessary to assess the effectiveness of the activities of municipal executive bodies instead of assessing local selfgovernment bodies, which include both the local administration and the representative body. This proposal is based on the analogy method - at the regional level, the efficiency of the executive branch is assessed, and "the municipal sector of the economy has almost the same sectoral structure as other sectors" [7, p. 27].

According to the authors, the voters - residents of the municipal territory, should assess the quality of the activities of the representative government. Different stakeholders, including residents, should carry out the assessment of the executive power in the municipality comprehensively.

\section{RESEARCH RESULTS}

The main executors of socio-economic policy on the territory of municipalities are municipal executive authorities, they organize the provision or directly provide municipal services to the population and carry out work to resolve issues 
of local importance, involve citizens in the management of the municipal economic complex.

Evaluation of the effectiveness of the activities of municipal executive authorities according to the author's method is of particular importance for the sectoral authorities of the region. Possessing a large amount of statistical data on the activities of sectoral divisions of municipal administrations, they can refine the federal criteria for assessing the effectiveness of activities, taking into account the tasks and conditions of development of the region as a whole and individual municipalities in the composition. Therefore, it is proposed to supplement the system of principles for assessment with the principle of professionalism and sectoral hierarchy, which are only partially implemented in the existing assessment of the effectiveness of local government bodies at the stage of indicators verification. In the author's procedural assessment model [12], the role of regional sectoral ministries increases at the stage of forming a

set of criteria and organizing expert analysis with the involvement of heads of municipal sectoral divisions (Figure1).

A significant addition to the current system for assessing the effectiveness of the activities of the municipal government is the development of directions for the application of the results of assessment based on high-quality economic diagnostics [23]: planning, forecasting, and stimulating the heads of municipal branch divisions, establishing official and personal responsibility [25, p.33] for achieving the required level of indicators. The proposed changes to the assessment procedure for local government bodies do not destroy it, but only strengthen the diagnostic function by professional analysis within the branches of the region. The importance of industry diagnostics diagnostics is also highlighted in materials of the UN Advisory Council on Economic and Social Issues [24, p. 64]. It is not correct to assess the activities of the municipal authorities based on the results achieved, since there is no known initial position on the financial and material security of the municipality to solve the problem of achieving the required indicator. Both the personnel and organizational components of the municipal sectoral divisions are unknown. In addition, the conditions for the management of a municipal formation can be both factors in the development of the municipal socio-economic system, and factors in the inhibition of this development. Failure to take into account the conditions distorts the assessment results.

The results of the study by the method of interviewing specialists of municipal administrations on the importance of conditions for management are presented in Table 2 .

TABLE 2. SIGNIFICANCE CONDITIONS EXPERT ASSESSMENT FOR MANAGEMENT IN THE MUNICIPALITY (COMPILED BY AUTHORS)

\begin{tabular}{|l|l|l|}
\hline \multicolumn{1}{|c|}{ Conditions } & $\begin{array}{l}\text { Significance } \\
\text { weight, \% }\end{array}$ & \multicolumn{1}{c|}{$\begin{array}{c}\text { Note } \\
\text { (most important aspects) }\end{array}$} \\
\hline Personnel & 21 & Specialists professionalism \\
\hline Organizational & 27 & $\begin{array}{l}\text { Status and authority of unit, its } \\
\text { information provision. }\end{array}$ \\
\hline Material & 17 & Fixed assets, infrastructure. \\
\hline Financial & 22 & $\begin{array}{l}\text { Providing authority with financial } \\
\text { resources. }\end{array}$ \\
\hline Sociogeographic & 13 & $\begin{array}{l}\text { Static, so compensatory activities is } \\
\text { required. It is not required to include } \\
\text { into cluster model conditions } \\
\text { assessment, but it should be taken } \\
\text { into account when assessment } \\
\text { results analyzing. }\end{array}$ \\
\hline
\end{tabular}

Thus, the interviewed experts do not deny the importance of the entire complex of existing conditions for the management of the municipal formation. However, organizational, financial, and personnel conditions are preferred in terms of the degree of influence on the result.

Assessment of the quality of conditions for management helps to identify the reasons for the ineffective actions of sectoral municipal units` responsible areas of implementation of socio-economic policy. Therefore, the author's procedural model is based on the systemic principle of the conditionality of the result.

The author's cluster model for assessing the effectiveness of the activities of municipal executive bodies is graphically displayed by the coordinate plane, where the complex indicator of conditions is located on the abscissa axis, and the complex indicator of results is located on the ordinate axis. The volumetric model becomes relevant when considering the results of the assessment in certain periods. The scale of divisions can be any: for example, from 0 to 100 units (points). All indicators for assessing conditions and results are transferred into a single measurement system, the price of a point is calculated, and the weight of each indicator is determined by an expert method. The division into clusters along both axes (conditions, result) can be carried out into 3 , 4, 5 large intervals, i.e. 9, 16, 25 clusters on a plane. For example, Figure 2 shows a sixteen-cluster assessment model.

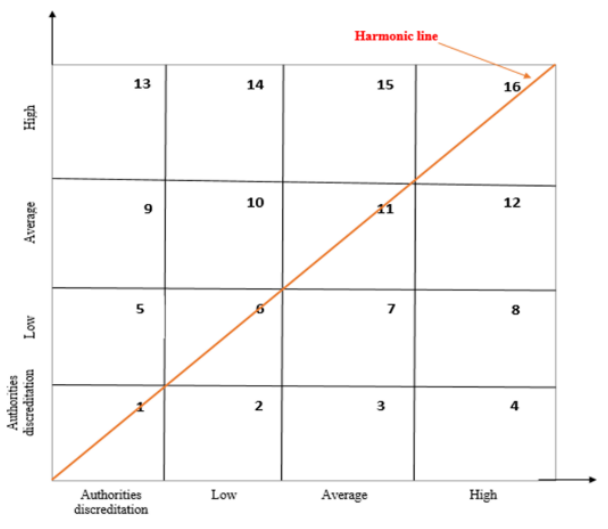

Fig.2 - Municipalities stratification model by clusters (compiled by authors)

Clusters: 1, 6, 11, 16 are harmonious, in which the ratio of conditions and results is considered proportional. However, the first and sixth clusters contain problematic municipalities. All clusters that are below the line of harmony require priority consideration, since, according to the logic of the model, the effectiveness of the governing bodies of the municipal formation in them is lower than it could be under the existing conditions. It is proposed to understand the efficiency of the activities of municipal authorities as to the ratio of the degree of achievement of goals in sustainable dynamics to the costs of creating conditions for the implementation of management tasks.

Thus, an approximate procedure for obtaining diagnostic data on the efficiency of the activities of municipal authorities in the sectoral context can be formed:

1) analysis of the conditions and results of the activities of municipal government bodies on the line of harmony, identification of problems and the reasons for their 
appearance in the management bodies of municipalities of the first and sixth cluster;

2) analysis of the conditions and results of the activities of municipal government bodies below the line of harmony, identification of problems and the reasons for their occurrence in municipalities that fall into clusters number 2 , $3,4,8,7,12$ (special attention to the first four of these); checking the influence of socio-geographic negative factors on the performance indicators;

3) analysis of the conditions and results of the activities of municipal authorities below the line of harmony, identification of reserves and development problems in municipalities that fall into clusters $5,9,10,13,14,15$; checking the influence of socio-geographic negative and positive factors on performance indicators.

According to research experience, it has been noted that it is very rare that municipalities are found that, according to the results of stratification, fall into the 13th and 4th clusters. This usually happens when there are errors in the criterion apparatus or the calculations of integral indicators.

Diagnostics of any phenomenon is inextricably linked with the study of the reasons for its appearance, in the light of the issue under consideration - the reasons for obtaining a certain indicator of efficiency. In the course of analyzing the reasons for the inclusion of a municipality in a particular cluster, to improve the quality of diagnostics, it is necessary to differentiate the integral indicators of conditions and results into smaller components and consider their critical values.

Table 3 presents possible diagnostic conclusions for one of the assessment indicators: "availability/lack of places in preschool educational institutions" and measures to improve the quality of diagnostics.

TABLE 3. AN EXAMPLE OF IMPROVING DIAGNOSTIC RESULTS QUALITY OF MUNICIPAL AUTHORITIES ACTIVITIES EFFECTIVENESS EVALUATING (AUTHORS` SCIENTIFIC RESULT)

\begin{tabular}{|c|c|c|c|c|}
\hline \multirow{5}{*}{ 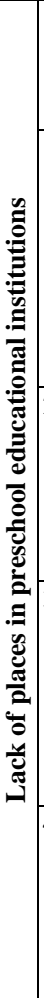 } & № & $\begin{array}{c}\text { Possible diagnostic } \\
\text { results }\end{array}$ & Optional diagnostic tests & $\begin{array}{c}\text { Municipal } \\
\text { problems source } \\
\text { (condition } \\
\text { indicator) }\end{array}$ \\
\hline & 1 & \begin{tabular}{|lr} 
Low & personnel \\
qualification & in \\
municipal executive \\
authorities r for \\
development \\
funding \\
constructiono
\end{tabular} & $\begin{array}{l}\text { Receipt of the necessary } \\
\text { funding; } \\
\text { personnel workload and } \\
\text { qualification involved in } \\
\text { funds development } \\
\text { organizational scheme of } \\
\text { assertion and documents } \\
\text { approval }\end{array}$ & $\begin{array}{l}\text { Financial } \\
\text { Personnel } \\
\text { Organizational } \\
\\
\end{array}$ \\
\hline & 2 & $\begin{array}{l}\text { High growth in the } \\
\text { child population }\end{array}$ & $\begin{array}{|lr|}\text { Accounting } & \text { and } \\
\text { forecasting } & \text { migration } \\
\text { indicators } & \text { socio- } \\
\text { geographical conditions } \\
\text { Registration } & \text { and forecast } \\
\text { fertility and mortality rates }\end{array}$ & $\begin{array}{l}\text { Socio- } \\
\text { geographic } \\
\text { conditions }\end{array}$ \\
\hline & 3 & $\begin{array}{l}\text { Preschool } \\
\text { educational } \\
\text { institutions } \\
\text { significant shortage }\end{array}$ & $\begin{array}{l}\text { Material base initial } \\
\text { conditions and condition } \\
\text { (fixed assets) } \\
\text { Correspondence material } \\
\text { base to municipality needs } \\
\text { of the in the present and } \\
\text { forecast }\end{array}$ & Material \\
\hline & 4 & $\begin{array}{lr}\text { Wasteful use } & \text { and } \\
\text { poor } & \text { quality } \\
\text { maintenance } & \text { of } \\
\text { preschool } & \\
\text { educational } & \\
\text { institutions } & \\
\end{array}$ & $\begin{array}{l}\text { Funding availability for } \\
\text { repair and maintenance } \\
\text { Maintenance quality } \\
\text { Buildings maintenance } \\
\text { solutions quality }\end{array}$ & $\begin{array}{l}\text { Financial } \\
\text { Personnel }\end{array}$ \\
\hline
\end{tabular}

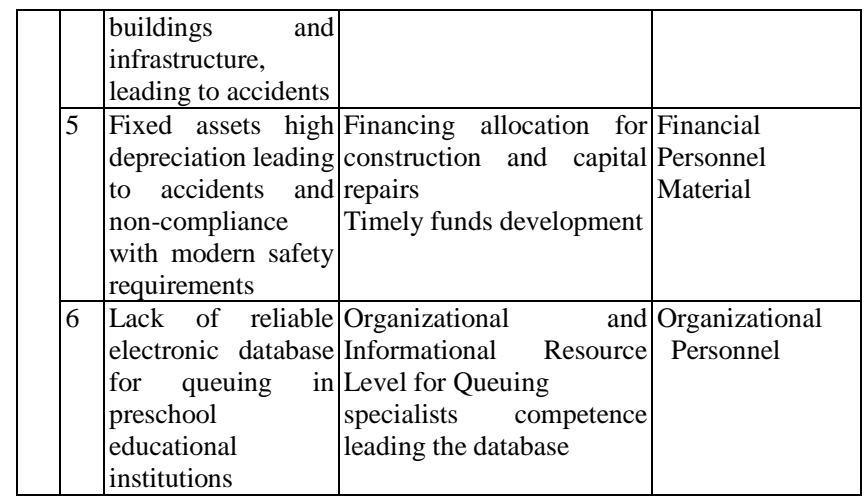

The task of the regional executive authorities in analyzing the results of grouping by clusters is complicated by the problem of finding optimal conditions for obtaining the necessary development result and solving the issue of compensating for the missing (or negative) conditions for managing a particular municipal formation. For example, distance from a regional center could be offset by a transportation subsidy; the complexity of living conditions in mountainous or arid municipal areas - with an increasing coefficient to salary; depressive border municipalities need a scientifically based policy in the foreign economic area, solving problems of a legislative nature when performing the function of the country's "barrier", "band" of cross-border exchange" [15].

Thus, when applying the method of volumetric clusters, the indicators of state socio-economic policy concerning local self-government do not change, it is just that the policy becomes more targeted, specific and requires professionalism from regional managers in studying the environment in which the goals of the policy are implemented and in making decisions on leveling it negative influences.

To improve the quality of diagnosis of problems and management reserves of a municipal entity, regional sectoral bodies will have to consider each indicator that is of critical importance separately in the cluster model. This process is greatly facilitated with the help of special software, which automatically makes the necessary calculations and visualizes clustering. When developing such regional software, the objectivity of the assessment increases, confidence in the results increases, the working time of experts is optimized, and a statistical data bank is created for the regional administration [26], which allows making informed decisions on planning the allocation of resources necessary to achieve the target indicators of socio-economic policy

\section{CONCLUSION}

Thus, the diagnostic function of the system for assessing the activities of municipal authorities plays an important role in the planning and forecasting system in the management of the region. The quality of the diagnostic function grows taking into account the conditions of management and the peculiarities of the development of municipalities in the region and an increase in the competence of specialists of regional sectoral ministries to clarify federal criteria based on the tasks of socio-economic policy and available resources. The introduction of an expert analysis of the heads of municipal branch divisions qualitatively changes the formation of the criteria apparatus for assessment, eliminating the shortcomings of the existing passive method. 
The model for assessing the effectiveness of the activities of municipal executive authorities proposed by the authors creates the preconditions for the transition to a different quality of planning for the development of municipalities and industries in the region based on the principles of system analysis and the introduction of modern digital technologies for decision-making based on the results of the assessment and at the same time does not break the existing system of assessing effectiveness activities of local government bodies.

\section{REFERENCES}

11] Decree of the President of the Russian Federation dated April 28, 2008 , No. 607 "On assessing the effectiveness of the activities of local selfgovernment bodies in urban districts and municipal districts". URL: http://www.kremlin.ru/acts/bank/27276, (accessed 11.09.2020).

[2] Order of the Government of the Russian Federation of No. 1313-r On the implementation of the Decree of the President of the Russian Federation of 28.04.2008 No. 607, On assessing the effectiveness of local government bodies in urban districts and municipal districts. URL: http://www.consultant.ru/ (accessed 11.08.2020).

[3] Decree of the Government of the Russian Federation of December 17 2012, N 1317 On measures to implement the Decree of the President of the Russian Federation of April 28, 2008 N 607, On assessing the effectiveness of local government bodies in urban districts and municipal districts "and subparagraph" and " clause 2 of the Decree of the President of the Russian Federation of May 7, 2012 N 601 "On the main directions of improving the public administration system." URL: http://www.consultant.ru/ (accessed 19.11.2020).

[4] Order of Rosstat of November 29, 2011 N 472 "On the approval of statistical tools for organizing federal statistical monitoring of the state of the economy and social sphere of the municipality", "Questions of statistics." N 2.2012. URL: http://www.gks.ru (accessed 20.11. 2020).

[5] A.G. Balykhin, "The effectiveness of the activities of local governments as institutions of power in the assessment of the civilian population", Bulletin of Siberia, No. 3 (4), 2012, pp. 210-215.

[6] O.I. Belyaeva, Methodological aspects of assessing the effectiveness of the implementation of the strategy of socio-economic development of the municipality. Abstract of the dissertation of the candidate of economic sciences. Specialty: 08.00.05 - Economics and National Economy Management (Regional Economics), Kaliningrad, 2014, 24 p.

[7] F.K. Bykova, V.V. Tabolskaya, Municipal economics and municipal management: textbook, Naberezhnye Chelny, 2011, 217 p

[8] N.V. Voroshilov, "Evaluation of the effectiveness of regional policy for the development of municipalities", Bulletin of the Cherepovets State University, 7 (60), 2014, pp. 54-59.

[9] A. Gracheva, The. Development of a system for assessing the effectiveness of local government bodies. In the collection: Modern technologies in science and education - MTSE-2019. Proceedings of the II International Scientific and Technical Forum: vol.10, 2019, pp. 98-102.

[10] S.E. Zhura, "Problems of assessing the effectiveness of managing socio-economic systems", Russian Journal of Entrepreneurship, 2010 , vol. 11, No. 12 (2), pp. 11-16.

[11] R.M. Ibragimov, "Theoretical and methodological aspects of the effectiveness of municipal management", Economics and Management, 34 (127), 2019. URL : https: //cyberleninka.ru/, (accessed 17.11.2020).

[12] I.V. Korkishko, "Modeling the procedure for assessing the effectiveness of local government bodies", Regional problems of economic transformation, 2020, No. 3 (113), pp. 65-74.

[13] T.S. Korchagina, Assessment of the effectiveness of local governmen bodies. Dissertation of the candidate of economic sciences: 08.00 .05 (regional economy). Saransk. 2016. P. 239 URL: https://studizba.com/files/show/pdf/51559-8-dissertaciya.html, (accessed 10.10.2020).

[14] E.A. Lubashev, M.V. Lukin, Problems of assessing the effectiveness of the executive bodies of state and minicipal authorities in the Russian Federation. Theory and practice of service: economics, social sphere, technologies, 2012. URL: https://cyberleninka.ru/ (accessed 23.11.2020).
[15] V.A. Malyshev, E.A. Stryabkova, Features of the socio-economic development of border regions. Spatial development of territories. Collection of scientific papers of the International Conference, Belgorod, 2018. URL: https://www.elibrary.ru/ (accessed: 24.11.2020).

[16] T.V. Nesterova, "Methodology for calculating indicators of the effectiveness of the administration of a municipal formation based on a balanced scorecard", Bulletin of the Orenburg State University, No. 8 (72), 2007, pp. 131-136.

[17] T.S. Presnyakova, Evaluation of the effectiveness of local government bodies: Russian and foreign experience", Regionology, 2014. pp. 2024.

[18] E.N. Sabyna, M.N. Sabyna, "Improving the system for assessing the effectiveness of municipalities", Economy Profession, Business, 2018, No. 1 , pp. $75-80$.

[19] F.A. Sinyavsky The system of indicators of management efficiency in the socio-economic development of the municipality. Abstract of the dissertation of the candidate of economic sciences. Specialty: 08.00.05 - Economics and management of the national economy (regional economics) / Vladimir, 2010, $26 \mathrm{p}$

[20] E.V. Fugalevich, Assessment of the effectiveness of the administrations of municipalities in the system of state management of the regional economy. Abstract of the dissertation of the candidate of economic sciences. Specialty: 08.00.05 Economics and National Economy Management: Regional Economics, St. Petersburg, 2011, $20 \mathrm{p}$.

[21] A.V. Chagina, O.V. Vilchinskaya, "Problems of implementation of the mechanism for assessing the effectiveness of local government bodies", Bulletin BIST, No. 1 (5), 2010.

[22] A.V. Shchurilov, Improving the efficiency of local government bodies: organizational and managerial aspects. Dissertation of the $\mathrm{PhD}$ of economic sciences: specialty: 08.00.05 Economy and management of the national economy: the regional economy, Ivanovo, 2011,187 p.

[23] F. Sassi, M. McKee and J. Roberts, International Journal of Technology Assessment in Health Care, vol. 13, Issue 4, 1997, pp. 613-630 DOI: https://doi.org/10.1017/S0266462300010084.

[24] J.Y. Lin, P. Liu, Inclusive catch-up: the new structural economics approach. Recovering better: economic and social challenges and opportunities A compilation of the High-level Advisory Board on Economic and Social Affairs Published by the United Nations, Department of Economic and Social Affairs New York, New York, 2020 , pp. $52-68$

[25] Report of the European Committee on Local and Regional Democracy (CDLR) Prepared with the collaboration of Alba Nogueira Lypez Professor at Santiago de Compostela University, Spain, 2007, 61 p.

[26] J.K. Upadhyaya, N. Biswas, E. Tam, "A review of infrastructure challenges: assessing storm water system sustainability", Canadian Journal of Civil Engineering, 41(6), 2014, pp. 483-492. 